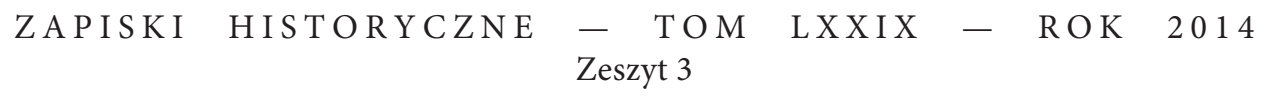

http://dx.doi.org/10.15762/ZH.2014.08

RADOSŁAW KRAJNIAK (Toruń)

\title{
JESZCZE O LEKARZACH W PAŃSTWIE ZAKONU KRZYŻACKIEGO W PRUSACH I ICH KARIERACH*
}

Tekst powstał w związku z lekturą książki Michaliny Brody poświęconej lekarzom z terenu państwa zakonu krzyżackiego w Prusach i kilkoma uwagami, które na jej marginesie się zrodziły ${ }^{1}$. Autorka publikacji to badaczka związana z toruńskim środowiskiem historycznym, która zdążyła już zaistnieć na polu naukowym dzięki kilku interesującym tekstom. Część spośród nich okazała się zapowiedzią recenzowanej pracy².

Wydana w 2013 r. przez Towarzystwo Autorów i Wydawców Prac Naukowych UNIVERSITAS książka, o czym informuje autorka we wstępie, „jest próbą analizy zagadnienia obecności lekarzy w granicach państwa zakonu krzyżackiego w Prusach" (s. 9). Wyniki badań zostały przedstawione w czterech rozdziałach podzielonych dodatkowo na bardziej szczegółowe podrozdziały. Pracę zamykają: zakończenie, bardzo istotny załącznik zawierający wykaz lekarzy występujących na terenie Prus do 1466 r., wykazy skrótów, źródeł i literatury oraz streszczenie w języku angielskim.

W rozdziale pierwszym, zatytułowanym Tło (s. 19-45), M. Broda podała w ciekawy sposób ogólne dane dotyczące rozwoju medycyny w Europie doby średniowiecza. Autorka przytoczyła w rozdziale m.in. najważniejsze traktaty medyczne, jak również nakreśliła etapy rozwoju medycyny jako dyscypliny uniwersyteckiej. Celem autorki, zrealizowanym zresztą z sukcesem, było poza tym nakreślenie sytuacji na najbliższym państwu zakonnemu kulturowo i geograficznie terenie. Przy-

* Artykuł powstał w związku z realizacją projektu „Prozopografia duchowieństwa diecezji warmińskiej w średniowieczu”. Projekt został sfinansowany ze środków Narodowego Centrum Nauki przyznanych na podstawie decyzji numer DEC-2011/03/N/HS3/01145.

${ }^{1}$ Michalina Broda, Lekarze w państwie zakonu krzyżackiego w Prusach w XIV-XV wieku, Towarzystwo Autorów i Wydawców Prac Naukowych UNIVERSITAS, Kraków 2013, ss. 226, ISBN 97883-242-2267-4.

${ }^{2}$ Zob. eadem, Bartłomiej z Boreszewa - dziekan warmiński, lekarz, dyplomata przełomu XIV-XV w., [in:] Ludzie, którzy zmienili bieg historii, red. Adam PIwEK, Wrocław 2010, s. 33-40; eadem, Lekarze pochodzący spoza państwa zakonnego $w$ Prusach $w$ otoczeniu wielkich mistrzów krzyżackich w XIV i pierwszej połowie XV stulecia, Zapiski Historyczne, t. 76: 2011, z. 3, s. 7-36; eadem, Żydowscy lekarze w państwie zakonu krzyżackiego w Prusach w późnym średniowieczu, Kwartalnik Historii Żydów, 2011, nr 3, s. 435-443. 
bliżona została czytelnikowi także m.in. działalność medyków na dworach władców czeskich, węgierskich i polskich.

Rozdział drugi pt. Kim byli? (s. 46-109) podzielony został na trzy części. W rozdziale tym poznajemy pierwszego, zdaniem M. Brody, lekarza na obszarze państwa zakonnego, magistra Frugeriusa, a także imiona kolejnych poświadczonych na tym terenie medyków, którzy znajdowali się w otoczeniu zwierzchników zakonu krzyżackiego, jak również tych, którzy prowadzili działalność w największych ośrodkach miejskich państwa zakonnego w Prusach (Toruniu, Elblągu i Gdańsku). W rozdziale przedstawiona została także działalność chirurgów i okulistów.

W rozdziale trzecim zatytułowanym Skąd pochodzili? (s. 110-129) M. Broda zajęła się kwestią pochodzenia lekarzy. W pierwszym z podrozdziałów autorka omówiła postacie lekarzy pochodzących z terenu władztwa zakonu krzyżackiego w Prusach, w drugim natomiast medyków przybyłych z zagranicy.

W ostatnim, czwartym rozdziale pt. Czym się zajmowali? (s. 130-172) omówienia doczekały się wreszcie takie zagadnienia, jak diagnozy lekarskie, leczenie, działalność dyplomatyczna medyków i ich dochody.

Bardzo ważnym uzupełnieniem rozważań autorki jest załącznik przedstawiający w formie tabeli wykaz lekarzy występujących na terenie Prus do $1466 \mathrm{r}$. (s. 179-202).

Z uznaniem należy się odnieść do wykorzystanej przez autorkę bazy źródłowej i literatury przedmiotu. M. Broda na potrzeby swoich badań, poza wykorzystaniem źródeł drukowanych, kwerendą objęła materiał archiwalny przechowywany w Berlinie, Toruniu i Gdańsku. Zapoznała się także z licznymi zagranicznymi opracowaniami naukowymi i to napisanymi w kilku językach (niemieckim, francuskim, czeskim, litewskim, angielskim, a nawet węgierskim). Wagę podniesionego tematu, jak również umiejętności badawcze autorki podkreślali, o czym dowiadujemy się z fragmentów recenzji, profesorowie Antoni Gąsiorowski i Tomasz Jasiński.

Nie ma jednak prac doskonałych, a rolą recenzji jest zwrócenie uwagi na pewne niedociągnięcia, nieścisłości i braki, jakie niesie ze sobą treść danej książki. Nieco uwag nasuwa się również w związku z lekturą pracy M. Brody.

Jeszcze we wstępie autorka informuje, że najwcześniej poświadczony źródłowo lekarz na badanym obszarze pojawia się dopiero w 1323 r. (s. 11)3. Wydaje się jednak, że za pierwszego lekarza uznać należy odnotowywanego w źródłach jako „phisicus”, magistra Arnolda ${ }^{4}$. Duchowny ten przypuszczalnie pochodził z Italii

\footnotetext{
${ }^{3}$ Informację tę powtarza także później, zob. eadem, Lekarze w państwie zakonu krzyżackiego w Prusach, s. 30; s. 46, przyp. 2, gdzie czytelnik raz jeszcze dowiaduje się o braku przekazów źródłowych poświadczających lekarzy na badanym obszarze w XIII w. Zob. też ibid., s. 47, 173.

${ }^{4}$ Jako pierwszego medyka na badanym obszarze odnotowuje go także wcześniejsza literatura, zob. Słownik biograficzny kapituły warmińskiej, red. Jan Guzowski, Olsztyn 1996 (dalej cyt. SBKW), s. 12. Por. też jego wcześniejszy biogram: Hans Sснмauch, Arnold, [in:] Altpreußische Biographie, hrsg. v. Christian Krollmann, Bd. 1, Marburg an der Lahn 1974, s. 18. Zob. też: Franz Hipler, Nikolaus Kopernikus und Martin Luther. Nach ermländischen Archivalien, Zeitschrift für die Geschichte und Alterthumskunde Ermlands (dalej cyt. ZGAE), Bd. 4: 1896, s. 484; Bibliotheca Warmiensis oder
} 
i 28 VI 1280 r. dowodnie po raz pierwszy wystąpił jako kanonik warmiński ${ }^{5}$. Tożsamy z nim jest zapewne „Magister Arnoldus”, który w 1294 r. w Braniewie był świadkiem na dokumencie biskupa warmińskiego Heinricha Fleminga ${ }^{6}$. Następnie, znów jako kanonik, Arnold poświadczony został 8 VII 1310 r. we Frombor$\mathrm{ku}^{7}$. W składzie tamtejszego kolegium odnotowuje go jeszcze kilka późniejszych źródeł, aż do 29 VI 1317 r. ${ }^{8}$ W wystawionym bez daty dziennej, w 1310 r., w Braniewie dokumencie odnotowany został również jako kanonik i pleban w Radzyniu (diecezja chełmińska) ${ }^{9}$. Jest jednak mało prawdopodobne, by rzeczywiście posiadał to beneficjum, skoro jako tamtejszy pleban, w okresie dowodnie od 5 XI 1305 do 4 III 1311 r., odnotowywany jest inny kanonik warmiński Peter ${ }^{10}$. Być może Arnoldowi probostwo w Radzyniu zostało dopisane przez pomyłkę, nie możemy wszak wykluczyć błędu pisarza ${ }^{11}$. Problemu nie rozwiązuje niestety lektura dwóch średniowiecznych odpisów tego dokumentu z ksiąg przywilejów kapituły przechowywanych w Archiwum Archidiecezji Warmińskiej w Olsztynie. Tam również Arnold widnieje w 1310 r. jako pleban w Radzyniu ${ }^{12}$.

Mimo że M. Broda we wstępie napisała, iż w książce za lekarzy uznaje osoby legitymujące się tytułami magistra czy też doktora w dziedzinie medycyny, które określane były terminami „medicus”, „physicus”, „Bucharzt” (s. 9), wydaje się, że do grupy medyków należałoby zaliczyć również te osoby, które w materiale źródłowym określone zostały jako mające licencjat czy też bakalaureat $\mathrm{z}$ medycyny. Autorka w załączonym wykazie lekarzy umieszcza zresztą osoby, które tak jak Jan Pomorzanin (s. 181-182), Nicolaus Mughe (s. 184) i Mikołaj Meltzer (s. 199), miały „jedynie” odpowiednio bakalaureat (dwaj pierwsi) i licencjat z zakresu nauk medycznych. W analizowanym okresie na obszarze państwa zakonu krzyżackiego

Literaturgeschichte des Bisthums Ermland, hrsg. v. Franz HipleR, Bd. 1: Abriss der ermländischen Literaturgeschichte nebst dem Spicilegium Copernicanum (Monumenta Historiae Warmiensis oder Quellensammlung zur Geschichte Ermlands, Bd. 4; 3. Abtheilung: Bibliotheca Warmiensis, Bd. 1), Braunsberg-Leipzig 1872, s. 282.

${ }^{5}$ Codex diplomaticus Warmiensis oder Regesten und Urkunden zur Geschichte Ermlands (dalej cyt. CDW), Bd. 1: Urkunden der Jahre 1231-1340, hrsg. v. Carl Peter Woelky, Johann Martin SAAge (Monumenta Historiae Warmiensis oder Quellensammlung zur Geschichte Ermlands, Bd. 1, Abtheilung 1), Mainz 1860, nr 57.

${ }^{6}$ Ibid., nr 93.

${ }^{7}$ Ibid., nr 154.

${ }^{8}$ Zob. ibid., nr 158 (4 III 1311 r.), nr 160 (1 VI 1311 r.), regest nr 263, s. 93 (2 VII 1312 r.), nr 166 (19 XII 1312 r.), nr 195 (7 V 1314 r.), nr 180 (29 VI 1317 r.). Zob. też: Viktor RöHRICH, Die Kolonisation des Ermlandes, ZGAE, Bd. 13: 1901, s. 873.

${ }^{9} \mathrm{CDW}, \mathrm{Bd} .1$, nr 157.

${ }^{10}$ Ibid., nr 133-134 (5 XI 1305 r.), nr 142-143 (12 VIII 1308 r.), nr 154 (8 VII 1310 r.), nr 158 (4 III 1311 r.).

${ }^{11}$ Zdaje się, że pisarz redagujący ów dokument po magistrze Arnoldzie zapomniał dopisać imienia Peter. W takiej kolejności zostali przecież wymienieni później, tj. 4 III 1311 r. (zob. CDW, Bd. 1, nr 158).

${ }^{12}$ Por. Archiwum Archidiecezji Warmińskiej w Olsztynie (dalej cyt. AAWO), Archiwum Kapituły, E, k. 7r-7v; F, k. 8v-9r. 
znamy przynajmniej jeszcze trzy takie osoby: Johanna von Mindena**, Nikolausa Mackowo i Heinricha Saszleina. Przyjrzyjmy się ich karierom.

Johann von Minden („de Minda”, „de Minden”, „de Mynda”, „de Mynden”, „Mynden”, „von Myndin”) ${ }^{13}$ pochodził być może z Elbląga, ze znanej rodziny mieszczańskiej, która do Prus przybyła zapewne z niemieckiego Minden. Urodził się w pierwszych dziesięcioleciach XIV w. Krewnymi jego byli przypuszczalnie przedstawiciele władz Starego Miasta Elbląga: Tidemanus de Minden, rajca odnotowywany w latach $1325-1353^{14}$, i Johannes Minden, rajca w latach $1338-1348^{15}$. Bliskim jego krewnym mógł być również Hermann van Mynden, mieszczanin elbląski odnotowany w $1371 \mathrm{r}^{16} \mathrm{~W}$ latach $1345-1352$ na uniwersytecie w Paryżu obecny jest dodatkowo Henricus de Minda, a w latach 1347-1348 jego brat Conradus $^{17}$. Od 1348 do 1350 r. widzimy tam jeszcze Dechardusa de Mindena ${ }^{18}$. Wszyscy oni, odnotowani na uniwersytecie w tym samym niemal czasie co Johann, są być może spokrewnieni $z$ interesującym nas duchownym.

Pierwszym znanym beneficjum, jakie objął Johann, była plebania kościoła parafialnego pw. Trzech Króli w Nowym Mieście Elblągu. Parafię objął z całą pewnością przed 3 XI 1374 r. ${ }^{19}$ Tego dnia jako pleban nowomiejski uzyskał prowizję na prepozyturę św. Piotra poza murami Moguncji. Beneficjum tego najpewniej nigdy jednak nie objął. Po raz ostatni jako pleban elbląskiej parafii nowomiejskiej odnotowany został 12 I $1377 \mathrm{r}^{20}$ Jeszcze w tym samym roku, 28 maja, po raz pierwszy

** Niemieckie przydomki posesjonatywne w przypadkach zależnych są w tekście odmieniane zgodnie z zaleceniami Redakcji „Zapisek Historycznych”.

${ }^{13}$ Por. jego biogramy: SBKW, s. 168; Mieczysław JózefCZYK, Elbląskie duchowieństwo katolickie na tle dziejów miasta 1246-1945, Elbląg 2005, s. 82. Zob. też: Wiesław DŁUGoKĘCKI, Elita władzy miasta Malborka w średniowieczu, Malbork 2004, s. 82; Piotr OLIŃski, Cysterskie nekrologi na Pomorzu Gdańskim od XIII do XVII wieku, Toruń 1997, s. 93-94. O nim krótko również: Edward CARSTENN, Geschichte der Hansestadt Elbing, Elbing 1937, s. 173-174, 177.

${ }^{14}$ Roman CzajA, Urzędnicy miejscy Elblaga do 1524 roku, Elbląg 2010, s. 26-42.

${ }^{15}$ Ibid., s. 33-39.

${ }^{16}$ CDW, Bd. 2: Urkunden der Jahre 1341-1375 nebst Nachträgen von 1240-1340, hrsg. v. Carl Peter WoelKY, Johann Martin SAAge (Monumenta Historiae Warmiensis oder Quellensammlung zur Geschichte Ermlands, Bd. 2, Abtheilung 1), Mainz 1864, nr 453.

${ }^{17}$ Liber Procuratorum Nationis Anglicanae (Alemanniae) in Universitate Parisiensi, t. 1: Ab anno 1333 usque ad annum 1406, edd. Henricus Denifle, Aemilius Chatelain, Paris 1894, szp. 80, 103, 106, 108, 113-116, 119, 121, 123, 125-130, 132-134, 136, 138, 142-145, 148-152, 154, 156-157, 161, 166. Zauważmy jednak, że Henricus bywa określany jako „de provincia Saxonie”.

${ }^{18}$ Ibid., szp. 115, 142, 144.

${ }^{19} \mathrm{CDW}, \mathrm{Bd} .2, \mathrm{nr} 490$. W literaturze przedmiotu niekiedy błędnie podawano datę 13 listopada, zob. SBKW, s. 168; W. DŁUGoKĘCKI, Elita władzy, s. 82. Pod rokiem 1374 jako pleban elbląski wymieniony został również w wykazie plebanów kościołów miejskich z diecezji warmińskiej, zob. Die Pfarrer an den ermländischen Stadtkirchen, Pastoralblatt für die Diözese Ermland, Jg. 9: 1875, s. 100. Zob. też: Scriptores rerum Warmiensium oder Quellenschriften zur Geschichte Ermlands (dalej cyt. SRW), Bd. 1, hrsg. v. Carl Peter Woelky, Johann Martin SAAGE (Monumenta Historiae Warmiensis oder Quellensammlung zur Geschichte Ermlands, Bd. 3, Abtheilung 2), Braunsberg 1866, s. 408, przyp. 106.

${ }^{20}$ CDW, Bd. 3: Urkunden der Jahre 1376-1424 nebst Nachträgen, hrsg. v. Carl Peter WoeLKY (Monumenta Historiae Warmiensis oder Quellensammlung zur Geschichte Ermlands, Bd. 5, Abtheilung 1), Braunsberg-Leipzig 1874, nr 644. 
określony został natomiast plebanem malborskim ${ }^{21}$. Jako taki odnotowany został jeszcze w lutym 1404 r. ${ }^{22}$ oraz w nekrologu klasztoru pelplińskich cystersów, którzy w księdze zmarłych pod datą dzienną 15 września umieścili go jako swego dobroczyńcę $^{23}$. Plebanię malborską zachował Johann najpewniej do śmierci.

Duchowny w trakcie swojej kariery został również członkiem warmińskiej kapituły katedralnej. Po raz pierwszy z godnością tą wspomniano go 12 I 1377 r. Kolejny raz jako kanonik odnotowany został w marcu tego roku ${ }^{24}$. W związku z posiadanymi beneficjami plebańskimi, najpierw w Elblągu, a następnie w Malborku, Johann nie mógł zapewne rezydować przy katedrze fromborskiej. Z powodu niewypełniania kanonickich obowiązków popadł zresztą w spór ze swoją kapitułą ${ }^{25}$. Johann tłumaczył wówczas, że obowiązki, które pełnił lub ma pełnić na dworze wielkiego mistrza, zwalniają go ze wszystkich kanonickich powinności ${ }^{26}$. Sprawa znalazła swój finał na sądzie polubownym, w skład którego weszli: prepozyt pomezański Johann von Riesenburg ${ }^{27}$, Pilgrim, ksiądz zakonny z Malborka, proboszcz w Lichnowach Johann Wildenberg oraz Johann - proboszcz lubieszewski i oficjał pomezański. Wyrok sądu, jak podaje dokument z 28 V 1377 r., okazał się korzystny dla Johanna, któremu kapituła winna była wypłacać na św. Marcina 20 grzywien, niezależnie, czy ten będzie aktywnie uczestniczył w życiu kapituły, czy też nie ${ }^{28}$. Jako kanonik warmiński poświadczony jest jeszcze 5 XII 1389 r. ${ }^{29}$ Być może godność tę zachował do końca życia.

Johann w źródłach określany jest jako magister sztuk wyzwolonych i bakałarz medycyny. Johannes de Minda, który jest obecny w Paryżu w latach 1349-1358, w tym od 1352 r. jako magister ${ }^{30}$, i „Magister Johannes de Mynda”, który w 1357 r. zostaje tam prokuratorem nacji angielskiej ${ }^{31}$, to najpewniej osoby tożsame $\mathrm{z}$ na-

${ }^{21}$ Ibid., nr 35.

${ }^{22}$ Das Marienburger Tresslerbuch der Jahre 1399-1409, hrsg. v. [Erich] JoAchiм, Königsberg i. Pr. 1896, s. 290. Wiemy, że Johann jako pleban malborski miał swojego kapelana. Osoba pełniąca tę funkcję, choć bez podania imienia, została odnotowana w 1403 r. w księdze malborskiego skarbnika, zob. ibid., s. 275. Zauważył to już Wiesław Długokęcki, zob. idem, Elita władzy, s. 84.

${ }^{23}$ P. Oliński, Cysterskie nekrologi, s. 94.

${ }^{24}$ Die Berichte der Generalprokuratoren des Deutschen Ordens an der Kurie, Bd. 1: Die Geschichte der Generalprokuratoren von den Anfängen bis 1403, bearb. v. Kurt ForstreuteR, Göttingen 1961, nr 154.

${ }^{25}$ Por. dokumenty dotyczące sporu: CDW, Bd. 3, nr 35, 644-646.

${ }^{26}$ M. JóZEFCZYK, op.cit., s. 82.

${ }^{27}$ Szeroko o nim: Mario Glauert, Das Domkapitel von Pomesanien (1284-1527), Toruń 2003, s. $468-470, \mathrm{nr} 81$.

${ }^{28} \mathrm{CDW}, \mathrm{Bd} .3$, nr 35 .

${ }^{29}$ Repertorium Germanicum. Verzeichnis der in den päpstlichen Registern und Kameralakten vorkommenden Personen, Kirchen und Orte des Deutschen Reiches, seiner Diözesen und Territorien vom Beginn des Schismas bis zur Reformation (dalej cyt. RG), Bd. 2: Verzeichnis der in den Registern und Kameralakten Urbans VI., Bonifaz' IX., Innocenz' VII. und Gregors XII. vorkommenden Personen, Kirchen und Orte des Deutschen Reiches, seiner Diözesen und Territorien: 1378-1415, bearb. v. Gerd Tellenbach, Berlin 1933-1938, szp. 701.

${ }^{30}$ Liber Procuratorum, t. 1, szp. 130, 145, 161, 205-206, 232.

${ }^{31}$ Ibid., szp. 206. 
szym duchownym. Wiesław Długokęcki przypuszcza, że może tak jak pleban malborski Johann Rode ${ }^{32}$ również kolejny pleban w tym mieście, właśnie Johann von Minden, był lekarzem wielkiego mistrza ${ }^{33}$. Kusząca w związku z tym byłaby próba łączenia Johanna von Mindena ze znanym M. Brodzie tylko z imienia lekarzem wielkiego mistrza wzmiankowanym w latach 1400-1405 (s. 185). Medyk ten, jeśli założymy, że przez cały ten okres mamy do czynienia z jedną osobą, był jednak odnotowywany jeszcze pod koniec 1405 r., czyli w momencie kiedy Johann von Minden już nie żył. Z ustaleniem daty śmierci duchownego wiążą się zresztą pewne problemy. Teresa Borawska pisała, że Johann zmarł przed 26 VI 1405 r. Tego bowiem dnia prowizję na kanonię warmińską wakującą po śmierci Johanna von Mindena otrzymał Johann Lodel ${ }^{34}$. Oficjał pomezański w swojej kronice pod datą 8 XII 1407 r. pisał z kolei, że duchowny nie żył od dwóch i pół roku ${ }^{35}$. Ta informacja wskazywałaby na zgon Johanna w pierwszym półroczu 1405 r. Nekrolog pelpliński odnotował go z kolei pod data dzienną 15 września $^{36}$. Mieczysław Józefczyk i Mario Glauert uznali, że Johann zmarł 15 IX $1405 \mathrm{r}^{37}$ Jako że papieska prowizja z czerwca 1405 r. dla Johanna Lodela jasno dowodzi, że Johann von Minden wówczas już nie żył, opowiadałbym się tym samym za pierwszą połową roku 1405 jako najbardziej prawdopodobnym terminem jego zgonu. Duchowny spoczął w malborskim kościele parafialnym, a z kroniki oficjała pomezańskiego dowiadujemy się, że jego grób został po pewnym czasie splądrowany, a zwłoki zbezczeszczone ${ }^{38}$.

Mniej informacji mamy niestety o kolejnych dwóch pominiętych przez M. Brodę lekarzach, choć Nikolaus Mackowo znany ze źródła datowanego na dzień 14 XI 1389 r., kiedy jako subdiakon, magister sztuk wyzwolonych i bakałarz medycyny, a także rektor ołtarza św. Stefana w kościele parafialnym pw. Najświętszej Marii Panny w Chełmnie, toczący spór o kanonię i prebendę poznańską, otrzymał ekspektatywę na beneficjum należące do kollacji biskupa warmińskiego ${ }^{39}$, jest być może tożsamy z późniejszym plebanem przy parafii św. Jakuba w Nowym Mieście Toruniu, znanym ze źródeł jako Nikolaus Mockow (Mockaw) ${ }^{40}$. Ten wzmiankowany w 1384 r. na uniwersytecie w Pradze bakałarz, w 1404 r. kapłan diecezji pomezańskiej ${ }^{41}$, a od

\footnotetext{
${ }^{32}$ Jego karierę kościelną szczegółowo przedstawili: W. DŁUGokęCKI, Elita władzy, s. 81-82; M. Glauert, op.cit., s. 478-479, nr 85.

${ }^{33}$ W. DŁugokęCKI, Elita władzy, s. 82.

${ }^{34}$ Zob. RG, Bd. 2, szp. 1264.

${ }^{35}$ Zob. Scriptores rerum Prussicarum. Die Geschichtsquellen der preussischen Vorzeit bis zum Untergange der Ordensherrschaft (dalej cyt. SRP), Bd. 3, hrsg. v. Theodor Hirsch, Max Toeppen, Ernst Strehlke, Leipzig 1866, s. 287. Por. W. DŁugokęCKi, Elita władzy, s. 82, przyp. 42.

${ }^{36}$ SRW, Bd. 1, s. 296. Zob. też: P. Oliński, Cysterskie nekrologi, s. 93.

37 Taką datę podają również: M. GLAUERT, op.cit., s. 479; M. JózefCZyK, op.cit., s. 82.

${ }^{38}$ SRP, Bd. 3, s. 287-288; M. GLAUERT, op.cit., s. 479, przyp. 729; M. JózEFCzyK, op.cit., s. 82.

${ }^{39}$ RG, Bd. 2, szp. 912.

40 Zob. jego biogram w: Marcin Sumowski, Duchowni diecezjalni w średniowiecznym Toruniu. Studium prozopograficzne, Toruń 2012, s. 223-224.

${ }^{41}$ Duchowny w 1389 r. jako rektor ołtarza w kościele parafialnym w Chełmnie był duchownym diecezji chełmińskiej. W 1404 r. miał być duchownym pomezańskim, a już rok później jako ple-
} 
1405 r. pleban toruński w sporządzonym w 1411 r. testamencie uczynił bowiem zapis na rzecz ołtarza św. Stefana, a więc tego, którego był rektorem dowodnie w 1389 r. ${ }^{42}$

Drugi z pominiętych duchownych, Heinrich Saszlein, 3 VI 1428 r. określony został natomiast jako magister sztuk, licencjat medycyny i pleban kościoła parafialnego w Pasłęku ${ }^{43}$. Nic więcej o nim nie wiadomo.

Wśród nieuwzględnionych przez autorkę lekarzy, których karier nie będę jednak w tym miejscu szczegółowo prezentował, znaleźli się również Theodoricus Carin i Albert Schroter. Pierwszy z nich, pochodzący z Gdańska, na początku XV w. studiował w Wiedniu i Krakowie, a tytułował się m.in. bakałarzem i licencjatem medycyny $^{44}$. Albert Schroter to z kolei pochodzący z Torunia student paryski, boloński i rostocki, rektor uniwersytetu w Rostocku, który jeszcze przed 1422 r. był bakałarzem medycyny, a przed 1427 r. doktorem z zakresu tej nauki ${ }^{45}$. Do grona medyków pochodzących z Prus pominiętych w pracy M. Brody dodać należy również Petera Rogovusa, kanonika pomezańskiego, lekarza biskupa warmińskiego Johanna Stryprocka, który zaświadczał, że śmierć hierarchy nastąpiła na skutek otrucia ${ }^{46}$, dalej wspomnianego w 1395 r. magistra medycyny Johanna Besrotsa ${ }^{47}$, poświadczonego

ban toruński ponownie duchownym diecezji chełmińskiej. Jeśli Nicolaus Mocker, kapłan diecezji pomezańskiej, jest tożsamy ze znanym z pozostałych źródeł duchownym diecezji chełmińskiej, to musiało dojść tu do dwukrotnego przejścia duchownego z jednej diecezji do drugiej, co jednak jest zjawiskiem znanym, zob. Andrzej Radzimiński, Problemy metodyczne w badaniach duchowieństwa kapitulnego w Polsce średniowiecznej, [in:] Duchowieństwo kapitulne w Polsce średniowiecznej i wczesnonowożytnej. Studia nad pochodzeniem i funkcjonowaniem elity kościelnej, red. Andrzej RADzimińSKI, Toruń 2000, s. 168.

${ }^{42}$ Piotr Oliński, Fundacje mieszczańskie w miastach pruskich w okresie średniowiecza i na progu czasów nowożytnych (Chetmno, Toruń, Elblag, Gdańsk, Królewiec, Braniewo), Toruń 2008, s. 180.

${ }^{43}$ RG, Bd. 4: Verzeichnis der in den Registern und Kameralakten Martins V. vorkommenden Personen, Kirchen und Orte des Deutschen Reiches, seiner Diözesen und Territorien, 1417-1431, bearb. v. Karl August Fink, Berlin 1943, szp. 1275. Zob. też: Die Berichte der Generalprokuratoren des Deutschen Ordens, Bd. 3: Johann Tiergart (1419-1428), Halbbd. 2, bearb. v. Hans Koeppen, Göttingen 1971, nr 330 (źródło datowane na 16 V 1428 r.). Postać zauważyli już w literaturze: Wiesław DŁUGOKє̨CKI, Dzieje miasta Pasłęka w latach 1297-1454, [in:] Pastęk. Z dziejów miasta i okolic 1297-1997, red. Józef WŁodARski, Pasłęk 1997, s. 265; Jan WIśNIEWski, Kościoły i kaplice na terenie byłej diecezji pomezańskiej 1243-1821, Elbląg 1999, s. 331.

${ }^{44}$ Die Matrikel der Universität Wien, Bd. 1: 1377-1450, Lfg. 1, Graz-Köln 1954, s. 62 (spokrewniony z nim był z całą pewnością gdańszczanin Nikolaus Korin poświadczony tam w $1409 \mathrm{r}$., zob. ibid., s. 79); Album studiosorum Universitatis Cracoviensis, t. 1: Ab Anno 1400 an Annum 1489, Kraków 1887, s. 5; Acta facultatis Medicae Universitatis Vindobonensis (1399-1435), hrsg. v. Karl SCHrauf, Wien 1894, s. 16-17, 99. Zob. też: Robert RuciŃsKI, „Środowiska intelektualne wielkich miast pruskich w średniowieczu", Toruń 2005, s. 173 (maszynopis rozprawy doktorskiej, Archiwum Uniwersytetu Mikołaja Kopernika w Toruniu, sygn. WNH-14/133).

${ }^{45}$ Robert RuciŃski, Schroter Albert (przed 1392-1438), dr med., rektor uniw. w Rostocku, uczony, [in:] Toruński słownik biograficzny (dalej cyt. TSB), t. 3, red. Krzysztof Mikulski, Toruń 2002, s. $194-195$.

${ }^{46}$ SRW, Bd. 1, s. 32; Anton EICHнonN, Geschichte der ermländischen Bischofswahlen, ZGAE, Bd. 1: 1860, s. 116. Duchowny ten nie był znany M. Glauertowi, autorowi pracy o kapitule pomezańskiej.

${ }^{47}$ Codex diplomaticus Prussicus, Bd. 5, hrsg. v. Johannes Voigt, Königsberg 1857, nr 68. Zob. też: Die Akten des Kanonisationsprozesses Dorotheas von Montau von 1394 bis 1521, hrsg. v. Richard 
między 1402 a 1408 r. toruńskiego lekarza miejskiego odnotowanego w jednym ze źródeł jako „scientificus vir T., magister in artibus et baccalarius in medicina, nostrae civitatis physicus" ${ }^{38}$, czy wreszcie wzmiankowanego w 1408 r. w Padwie licencjata i doktora medycyny Maksimina de Pruxia ${ }^{49}$.

Kolejny duchowny mający wykształcenie medyczne, Johann Pomeranus, to postać znana M. Brodzie. Autorka książki podała całkiem sporo informacji dotyczących jego życia (s. 110-112), jednak nie znała kilku prac i źródeł szerzej oświetlających jego karierę, w tym obecność w składzie kapituły warmińskiej. Z tego powodu wypada pochylić się na tą postacią raz jeszcze.

Johann Pomeranus („de Pomarania”, „de Prucia”, „de Prucia dictus de Pomeren”, „Pomeranus de Prussia”, „Pomerarius de Brussia”) ${ }^{50}$ w źródłach często pojawia się jako pochodzący z Prus. Z pewnego źródła proweniencji papieskiej dowiadujemy się poza tym, że był klerykiem diecezji włocławskiej ${ }^{51}$. Studiował na uniwersytecie paryskim, uzyskując stopień magistra sztuk wyzwolonych ${ }^{52}$. Dnia 4 III 1356 r. odnotowany został jako „electus procurator nationis Anglicane” ${ }^{53}$. W Paryżu widzimy go jeszcze w 1357 r. ${ }^{54}$ Był też określany jako bakałarz medycyny ${ }^{55}$ i scholar

Stachnik, in Zusammenarbeit mit Anneliese Triller, geb. Birch-Hirschfeld, Hans Westpfahl, Köln-Wien 1978, s. 528.

${ }^{48}$ Hans Prutz, Über ein Formelbuch aus dem Anfange des fünfzehnten Jahrhunderts, Altpreußische Monatschrift, Bd. 6: 1869, s. 209.

${ }^{49}$ Acta graduum academicorum Gymnasii Patavini ab anno 1406 ad annum 1450, a cura di Gaspare Zonta, Giovanni Brotto, vol. 1: 1406-1434, Patavii 1922 (reprint: Padova 1970), s. 4-5, nr 14-15 (zob. też indeks).

${ }^{50}$ Por. jego biogramy w: SBKW, s. 194; Marek Daniel Kowalski, Prałaci i kanonicy krakowskiej kapituły katedralnej od pontyfikatu biskupa Nankera do śmierci biskupa Zawiszy z Kurozwęk (1320-1386), Kraków 1996, s. 182-183, nr 87; Krzysztof OżóG, Intelektualiści w stużbie Królestwa Polskiego w latach 1306-1382, Kraków 1995, s. 133; Gerhard SCHINDLER, Das Breslauer Domkapitel von 1341-1417. Untersuchungen über seine Verfassungsgeschichte und persönliche Zusammensetzung, Breslau 1938, s. 318. Jego krótki biogram skreślili również: Krzysztof OżóG, Kultura umysłowa w Krakowie w XIV wieku. Środowisko duchowieństwa świeckiego, Wrocław-Warszawa-Kraków-Gdańsk-Łódź 1987, s. 144; Jan FIJA£EK, O archidiakonach pomorskich i urzędnikach biskupich $w$ archidiakonacie pomorskim diecezji włocławskiej w XII-XV wieku, Roczniki Towarzystwa Naukowego w Toruniu, R. 6: 1899, s. 150-151. Wspomina także o nim kilkakrotnie w swojej pracy: Peter KRIEDTE, Die Herrschaft der Bischöfe von Włocławek in Pommerellen. Von den Anfängen bis zum Jahre 1409, Göttingen 1974, s. 209, 347, 351, 353.

${ }^{51}$ Zob. np. Bullarium Poloniae, t. 2: 1342-1378, edd. Irena SuŁKowsKa-Kuraś, Stanisław Kuraś, Romae 1985, nr 1124. Pochodził może tym samym z terenu archidiakonatu pomorskiego diecezji włocławskiej, który był częścią państwa zakonu krzyżackiego w Prusach.

${ }^{52}$ W Paryżu poświadczony jest przez szereg uniwersyteckich źródeł, zob. Liber Procuratorum, t. 1, szp. 190-192, 195-197, 207.

${ }^{53}$ Prussia scholastica. Die Ost- und Westpreussen auf den mittelalterlichen Universitäten, gesammelt v. Max Perlbach, Braunsberg 1895, s. 9. Zob. też: K. OżóG, Kultura umysłowa, s. 20.

${ }^{54}$ Liber Procuratorum, t. 1, szp. 207.

${ }^{55}$ Bullarium Poloniae, t. 2, nr 1138; Preussisches Urkundenbuch (dalej cyt. Pr. Urk.), Bd. 6, hrsg. v. Klaus ConRad, Marburg 1986, nr 101. 
prawa kanonicznego ${ }^{56}$. Adam Bednarski zakładał, że Johann jako lekarz działał we Włocławku ${ }^{57}$.

Johann Pomeranus 28 XI 1362 r. otrzymał prowizję na beneficjum należące do kollacji biskupa włocławskiego ${ }^{58}$. Z kolei 16 I 1363 r. dostał papieską prowizję na kanonię we Włocławku ${ }^{59}$. Prowizja ta powodowała kasację poprzedniej, na beneficjum należące do kollacji kapituły św. Gwidona w Spirze ${ }^{60}$. Przyjmuje się, że w latach 1368-1391 był archidiakonem pomorskim ${ }^{61}$. W dniu 9 XI 1389 r. papież zatwierdza jednak na archidiakonacie pomorskim, w związku z przejściem Johanna Pomeranusa na kustodię warmińską, Johanna Lopponiego ${ }^{62}$. Ten chyba jednak nie objął urzędu, skoro po śmierci Pomeranusa prowizję na archidiakonat otrzymał inny duchowny. Johann Pomeranus nie objąwszy fromborskiej kustodii, pozostał więc do końca życia archidiakonem pomorskim. Nie był natomiast, jak chce tego Krzysztof Ożóg ${ }^{63}$, a za nim także M. Broda (s. 112), mianowany w 1385 r. subkolektorem w diecezji włocławskiej. Tę funkcję kolektor Dobrogost powierzył bowiem Janowi, archidiakonowi włocławskiemu, który nie może być jednak tożsamy z Johannem Pomeranusem ${ }^{64}$.

W trakcie swojej kariery kościelnej duchowny został również kanonikiem gnieźnieńskim. Z godnością tą z całą pewnością odnotowany był już 24 IV 1380 r., gdy wśród innych kanoników gnieźnieńskich, nazwany dodatkowo archidiakonem pomorskim, świadkował w Gnieźnie na dokumencie arcybiskupa Jana ${ }^{65}$. Być może, a tak uważał niegdyś Jan Fijałek ${ }^{66}$, duchowny w składzie kapituły gnieźnieńskiej pojawił się już 13 II $1375 \mathrm{r}^{67}$ Wówczas to $\mathrm{w}$ testacji pewnego dokumentu niejaki Jan Pomeranus został określony archidiakonem. Brak pewności co do tego, że chodzi o archidiakonat pomorski, nieco komplikuje sprawę, niemniej skłaniam się ku temu, że mamy do czynienia z jedną osobą. Około 1378-1382 r. Johann

${ }^{56}$ Bullarium Poloniae, t. 3: 1378-1417, edd. Irena SuŁKowsKa-Kuraś, Stanisław Kuraś, Romae-Lublini 1988, nr 33.

${ }^{57}$ Adam Bednarski, Materiały do dziejów medycyny polskiej w XIV i XV stuleciu, Kraków 1939, s. 3 .

${ }^{58}$ Bullarium Poloniae, t. 2, nr 1124.

${ }^{59}$ Pr. Urk., Bd. 6, nr 101-102; Bullarium Poloniae, t. 2, nr 1138.

${ }^{60}$ M.D. Kowalski, op.cit., s. 182.

${ }^{61}$ Pierwszy raz odnotowany został z tą godnością $26 \mathrm{~V} 1368$ r., zob. Bullarium Poloniae, t. 2, nr 1596. Zob. też inne źródła poświadczające go na tym urzędzie: ibid., nr 1739 (22 IV 1371 r.), 2349 (28 VIII 1376 r.).

${ }^{62} \mathrm{RG}$, Bd. 2, szp. 684.

${ }^{63}$ K. OżóG, Intelektualiści, s. 133.

${ }^{64}$ Por. Bullarium Poloniae, t. 3, nr 43. Zob. też: Stanisław Szczur, Skarbowość papieska w Polsce w latach 1378-1431, Kraków 2008, s. 182. Zauważmy, że w kapitule włocławskiej w średniowieczu odnotowywani byli trzej archidiakoni: kruszwicki, pomorski i włocławski, zob. Stanisław LiBRowSKI, Kapituła katedralna włocławska. Zarys dziejów i organizacji, Warszawa 1949, s. 20, 93-94.

${ }^{65}$ Jeszcze szesnaście nie drukowanych dokumentów arcybiskupów z XIV wieku, oprac. Stanisław Librowski, Archiwa, Biblioteki i Muzea Kościelne, t. 55: 1987, s. 113-114.

${ }^{66}$ J. FIJAŁEK, op.cit., s. 150.

${ }^{67}$ Kodeks dyplomatyczny Wielkopolski, t. 3, wyd. Ignacy Zakrzewski, Poznań 1879, nr 1716. 
otrzymał prowizję na kanonie w Krakowie i we Wrocławiu ${ }^{68}$. Marek Daniel Kowalski uważał, że kanonii wrocławskiej nie udało mu się objąć ${ }^{69}$, czemu przeczą jednak nieznane mu ustalenia Gerharda Schindlera, dzięki którym wiemy, że 15 IX 1381 r. Johann Pomeranus został jednak odnotowany jako kanonik wrocławski ${ }^{70}$. Otrzymał również prowizję na kanonię w Pradze, której to najpewniej nie objął ${ }^{71}$. Kanonikiem krakowskim i gnieźnieńskim pozostał do końca życia. Po jego śmierci na zwolnione beneficja prowizje otrzymali następni duchowni ${ }^{72}$.

Johann Pomeranus związany był również z kolegium kanoników fromborskich. W składzie kapituły warmińskiej obecny był dowodnie od 1387 r. ${ }^{73} \mathrm{~W}$ listopadzie 1389 r. miał zostać nawet kustoszem ${ }^{74}$, co spowodowało najpewniej spór z Tilonem von Glogowem, który już od 1387 r. posiadał tę prałaturę. Johann kustodii z pewnością nie objął. W tym momencie urywają się również informacje na temat jego dalszej aktywności w kolegium kanoników fromborskich.

Przez pewien czas związany był także z dworem króla węgierskiego Ludwika i jego matki Elżbiety, gdzie jako „clericus domesticus” odnotowany został około 1378-1382 $r{ }^{75} \mathrm{Z}$ racji wieloletniego posiadania archidiakonatu pomorskiego należał do bliskiego otoczenia biskupów włocławskich, głównie Zbyluta Pałuki, biskupa w latach 1364-1383.

Johann zmarł 15 IX 1391 r., a datę jego śmierci odnotował kalendarz katedry krakowskiej $^{76}$.

Nie do końca pełne są również informacje, jakie autorka podaje odnośnie do kariery kolejnego z duchownych, związanego czasowo z kapitułą warmińską Hermanna von Birkena. Spróbujmy więc przedstawić jak najpełniej karierę Hermanna raz jeszcze, starając się rozwiązać również problem jego medycznego wykształcenia, o którym dotychczas niewiele było wiadomo.

Hermann von Birken („de Berken”, „de Bircken”, „de Prussia”, „von Birken”) 77 urodził się w pierwszej ćwierci XV w. Zmarł natomiast najpewniej jeszcze w 1466 r.,

${ }^{68}$ Monumenta Vaticana res gestas Bohemicas illustrantia (dalej cyt. MVB), t. 5: Acta Urbani VI. et Bonifatii IX 1378-1404, opera Camilli Krofta, Pragae 1903, nr 87; Bullarium Poloniae, t. 3, nr 33. Kanonikiem w Krakowie nazywa go m.in. źródło datowane na dzień 30 IX 1390 r., zob. Kodeks dyplomatyczny katedry krakowskiej ś. Wacława, cz. 2: Obejmująca rzeczy od roku 1367 do roku 1423, wyd. Franciszek Piekosiński, Kraków 1883, s. 345-346.

${ }^{69}$ M.D. Kowalski, op.cit., s. 183, przyp. 4.

${ }^{70}$ G. Schindler, op.cit., s. 318. Zob. też: Wilhelm Schulte, Die politische Tendenz der Cronica principum Polonie (Darstellungen und Quellen zur schlesischen Geschichte, Bd. 1), Breslau 1906, s. 125, 242. Zauważył to później również: Robert SAMulski, Zu den Beziehungen zwischen Ermland und Schlesien, ZGAE, Bd. 26: 1938, s. 624.

${ }^{71}$ RG, Bd. 2, szp. 18.

${ }_{72}$ Bullarium Poloniae, t. 3, nr 260-262, 686; RG, Bd. 2, szp. 922, 1054-1055.

${ }^{73}$ CDW, Bd. 3, nr 358, s. 325.

${ }^{74}$ RG, Bd. 2, szp. 684; Bullarium Poloniae, t. 3, nr 96.

${ }^{75}$ Zob. Bullarium Poloniae, t. 3, nr 33. Por. MVB, t. 5, nr 87.

${ }^{76}$ Najdawniejsze roczniki krakowskie i kalendarz, wyd. Zofia KozŁowskA-Budкоwa (Pomniki dziejowe Polski, seria 2, t. 5), Warszawa 1978, s. 171. Zob. też: K. OżóG, Kultura umysłowa, s. 20.

${ }^{77}$ Zob. jego biogramy w: SBKW, s. 21; Anton EICHHorn, Die Prälaten des ermländischen Domcapitels, ZGAE, Bd. 3: 1866, s. 534. 
skoro jego następca na kustodii warmińskiej Christian Tapiau prałaturę tę przejął w styczniu roku $1467^{78}$. Pochodził z rodziny mieszczańskiej, najpewniej z Królew$\mathrm{ca}^{79}$. W 1437 r., gdy rozpoczynał kształcenie w Paryżu, określony został jako pochodzący z diecezji sambijskiej ${ }^{80}$. W $1441 \mathrm{r}$. odnotowany został z kolei jako kleryk tamtejszej diecezji ${ }^{81}$. Warto niemniej pamiętać, że rodzina von Birken w podobnym czasie aktywna była również w Toruniu ${ }^{82}$.

Hermann studia rozpoczął w 1437 r. w Paryżu ${ }^{83}$. Na tamtejszej wszechnicy uzyskał magisterium sztuk wyzwolonych ${ }^{84}$. Kształcenie kontynuował w Bolonii, gdzie poświadczony został w $1441 \mathrm{r}$. jako student prawa kanonicznego ${ }^{85}$. Tam w 1445 r. doktoryzował się prywatnie. Publiczna obrona odbyła się dopiero 25 IX 1456 r. ${ }^{86} \mathrm{~W} 1445$ i 1447 r. występuje w źródłach jako licencjat dekretów ${ }^{87}$. Część źródeł określała Hermanna również mianem doktora medycyny, jednak w dotychczasowej literaturze panowało przekonanie, że nie wiadomo, gdzie kształcił się na medyka i gdzie uzyskał stosowny stopień. Sprawę zdaje się rozwiązywać jednak zapis w aktach uniwersytetu padewskiego, gdzie pod datą 1 VII 1456 r. Hermann

${ }^{78}$ A. Eichiorn, Die Prälaten, s. 535.

${ }^{79}$ Za syna kupca z Królewca uznaje go Teresa Borawska, por. SBKW, s. 21.

${ }^{80}$ Liber Procuratorum Nationis Anglicanae (Alemanniae) in Universitate Parisiensi, t. 2: Ab anno 1406 ad annum 1466, edd. Henricus Denifle, Aemilius Chatelain, Paris 1897, szp. 493, 503; Liber Receptorum Nationis Anglicanae (Alemanniae) in Universitate Parisiensi, edd. Astricus Ladislaus GABRIEL, Gray Cowan Boyce, Paris 1964, szp. 80. Por. Hartmut Boockmann, Die preußischen Studenten an den europäischen Universitäten bis 1525, [in:] Historisch-geographischer Atlas des Preussenlandes, Lfg. 3, hrsg. v. Hans Mortensen, Gertrud Mortensen, Reinhard Wenskus, Wiesbaden 1973, s. 3.

${ }^{81}$ Karol Górski, Studenciz Prus w Bolonii w XIV i XV wieku, Komunikaty Mazursko-Warmińskie, 1989, nr 1-4, s. 9; SBKW, s. 21.

${ }^{82}$ Wybitny przedstawiciel toruńskiej rodziny von Birken, Rotcher, od 1438 r. pełnił najważniejsze funkcje we władzach Starego Miasta Torunia, zob. Roman Czaja, Urzędnicy miejscy Torunia do roku 1454, Toruń 1999, s. 197; Krzysztof MikUlski, Urzędnicy miejscy Torunia 1454-1650, Toruń 2001, s. 187. Zob. też: Irena JANosz-BISKupowa, Krzysztof MikULSKI, Birken Rutger (Rudiger) von (zm. 1472), burmistrz tor., [in:] TSB, t. 1, red. Krzysztof Miкulski, Toruń 1998, s. 29-30.

${ }^{83}$ Liber Procuratorum, t. 2, szp. 493; Liber Receptorum, szp. 80.

${ }^{84}$ Jako magister sztuk wyzwolonych występuje w szeregu późniejszych źródeł, por. Regesta historico-diplomatica Ordinis S. Mariae Theutonicorum 1198-1525, Ps. 2: Regesta privilegiorum Ordinis S. Mariae Theutonicorum, Regesten der Pergament-Urkunden aus der Zeit des Deutschen Ordens, bearb. unter Mitwirkung zahlreicher Anderer v. Erich JoAснiм, hrsg. v. Walther Нuвatsch, Göttingen 1948, nr 2582; RG, Bd. 5: Verzeichnis der in den Registern und Kameralakten Eugens IV. vorkommenden Personen, Kirchen und Orte des Deutschen Reiches, seiner Diözesen und Territorien: 1431-1447, bearb. v. Hermann Diener, Brigide Schwarz, Tübingen 2004, nr 3252; Geheimes Staatsarchiv Preußischer Kulturbesitz, Berlin-Dahlem, XX. Hauptabteilung (dalej cyt. GStA PK, XX. HA), Pergamenturkunden (dalej cyt. Perg.Urk.), Schieblade (dalej cyt. Schiebl.) 90, Nr. 6, 7 (tu także jako licencjat dekretów).

${ }^{85}$ Deutsche Studenten in Bologna (1286-1562). Biographischer Index zu den Acta nationis Germanicae universitatis Bononiensis, bearb. v. Gustav C. KNoD, Berlin 1899, s. 46, nr 321; Prussia scholastica, s. 204; Hartmut Boockmann, Laurentius Blumenau. Fürstlicher Rat-Jurist-Humanist (ca. 1415-1484), Göttingen 1965, s. 26; K. GóRsKI, op.cit., s. 9.

${ }^{86}$ Deutsche Studenten in Bologna (1286-1562), s. 46, nr 321; Prussia scholastica, s. 204; H. BoocKMANN, Laurentius Blumenau, s. 26; K. GóRsKI, op.cit., s. 9.

${ }^{87}$ Deutsche Studenten in Bologna (1286-1562), s. 46, nr 321; GStA PK, XX. HA, Perg.Urk., Schiebl. 90, Nr. 6, 7 (14 VIII 1447 r.). 
von Birken występuje jako licencjat dekretów oraz student medycyny ${ }^{88}$. Najpewniej w Padwie uzyskał więc kolejne stopnie z zakresu tej nauki.

Duchowny związany był również z fromborskim kolegium kanoników. Prowizję na kanonię i małą prebendę warmińską wakującą po śmierci Johanna Ulriciego otrzymał 3 X 1444 r. Jak informuje nas źródło proweniencji papieskiej, był już wówczas wikariuszem warmińskim (miał jednak przestać nim być po objęciu kanonii) i altarystą wrocławskim ${ }^{89}$. Kanonikiem warmińskim zostaje nazwany jeszcze w Bolonii - 7 IV 1445 r. ${ }^{90}$ Od 1447 r. na stałe rezydował jako kanonik przy katedrze fromborskiej ${ }^{91}$. Z dziekanem warmińskim Johannem Plastwichem jako przedstawiciel kapituły złożył w 1454 r. hołd królowi polskiemu². Dnia 24 VII 1461 r. w jego sprawie pisał do wielkiego mistrza biskup warmiński Paul Legendorf. Sprawa dotyczyła grabieży na Mierzei Wiślanej, jakiej na duchownym mieli się dopuścić ludzie z Fischhausen (Rybaki na Sambii). Jak dowiadujemy się z listu, łupem złoczyńców miała wówczas paść skrzynia z książkami³. Jako „her Herman van Buchen, doctor in der erczteye, licentiatus in geistlichen rechten und thumherre" 19 grudnia tego roku przebywał z kolei ze wspomnianym biskupem warmińskim i oficjałem Wernerem Medderichem w Elblągu ${ }^{94}$. W maju 1462 r. leczył m.in. komtura elbląskiego ${ }^{95}$. Źródło, które mówi o pomocy choremu dostojnikowi krzyżackiemu, M. Broda omówiła w swej pracy wyczerpująco (s. 131-132). T. Borawska podała, że w 1462 r. Hermann został po raz pierwszy odnotowany na kustodii warmińskiej ${ }^{96}$. Nie potwierdza tego jednak zachowany materiał źródłowy. Jeszcze 12 VIII 1462 r. Hermann von Birken występuje jako kanonik ${ }^{97}$. Kustoszem po raz pierwszy odnotowany został natomiast na początku kwietnia 1465 r. i godność tę zachował do końca życia ${ }^{98}$. Jak każdy z kanoników również Hermann miał

${ }^{88}$ Acta graduum academicorum Gymnasii Patavini. Ab anno 1451 ad annum 1460, a cura di Michele Pietro Ghezzo, Padova 1990, s. 140, nr 440.

${ }^{89} \mathrm{RG}, \mathrm{Bd} .5$, nr 3252.

${ }^{90}$ Deutsche Studenten in Bologna (1286-1562), s. 46, nr 321.

${ }^{91}$ Jako kanonika warmińskiego od tego czasu odnotowuje go szereg źródeł, zob. GStA PK, XX. HA, Ordensfolianten 16, s. $497-498$ (30 V 1447 r.); Perg.Urk., Schiebl. 90, Nr. 6,7 (14 VIII 1447 r.); AAWO, Dokumenty Kapituły (dalej cyt. Dok. Kap.), T 25 (5 I 1448 r.), P 43 (23 III 1448 r.); GStA PK, XX HA., Ordensbriefarchiv (dalej cyt. OBA), nr 10091 (10 XI 1449 r.); AAWO, Dok. Kap. L 83a (15 IX 1452 r.); Archiwum Państwowe w Gdańsku, 300D/42, nr 41 (20 IV 1454 r. - tego dnia kapituła upoważniła go do prowadzenia rozmów z władzami miasta Gdańska); GStA PK, XX. HA, OBA, nr 15662 (24 VII 1461 r.). Zob. też: A. EichHorn, Die Prälaten, s. 534.

${ }^{92}$ Związek Pruski i poddanie się Prus Polsce. Zbiór tekstów źródłowych, red. Karol Górski, Poznań 1949, s. 71-73.

${ }^{93}$ GStA PK, XX. HA, OBA, nr 15662.

${ }^{94}$ Acten der Ständetage Preussens unter der Herrschaft des Deutschen Ordens, Bd. 5, hrsg. v. Max ToEPPEN, Leipzig 1886, nr 24, s. 51.

${ }^{95}$ GStA PK, XX. HA, OBA, nr 15779.

${ }^{96}$ SBKW, s. 21. Wcześniej ten błąd popełnili Max Perlbach (zob. Prussia scholastica, s. 204) i Gustav C. Knod (zob. Deutsche Studenten in Bologna (1286-1562), s. 46, nr 321).

${ }^{97}$ AAWO, Dok. Kap., K1, nr 19, 25.

${ }^{98}$ Ibid., nr 1, 18. Zob. też: SRW, Bd. 1, s. 97, przyp. 97. Por. A. EICHHorn, Die Prälaten, s. 534. 
w katedrze swój ołtarz. Wiadomo, że ten sam ołtarz mieli później kanonicy Johann Zanau i Mikołaj Kopernik ${ }^{99}$. Jak podała T. Borawska, Hermann von Birken określany był również jako dobroczyńca klasztoru w Kartuzach ${ }^{100}$.

Na koniec chciałbym jeszcze zgłosić kilka drobniejszych uwag. Otóż M. Broda przedstawiając sylwetkę Siegfrieda Degenberga, słusznie na podstawie analizy źródeł wykazała, że pochodził z Prus. Zaznaczyła jednak, że w dotychczasowej literaturze przedmiotu przyjmowano, że duchowny pochodził ze szlacheckiego rodu z Bawarii (s. 113-114). Tak, za Cäcilie Kuchendorf ${ }^{101}$, rzeczywiście pochodzenie Siegrfieda Degenberga przedstawiali Kazimierz Dola i Stanisław Jujeczka ${ }^{102}$. Bawarskie pochodzenie duchownego nie jest jednak solidnie umocowane źródłowo i należy je odrzucić. Zauważyć trzeba jednak, że za jego pruskim pochodzeniem jednoznacznie opowiedziała się T. Borawska i stąd należy jej w tym ustaleniu przyznać palmę pierwszeństwa. M. Broda, mimo że deklaruje w swej bibliografii znajomość biogramu duchownego pióra T. Borawskiej, w żadnym miejscu swojej pracy (nie licząc Wstępu) go jednak nie wykorzystuje. Dużą zasługą autorki jest poprawienie ustaleń S. Jujeczki odnośnie do pierwszego pojawienia się Siegfrieda na dziekanii legnickiej oraz $\mathrm{w}$ charakterze przybocznego medyka króla węgierskiego Zygmunta Luksemburskiego. Przejęła jednak za wrocławskim historykiem szereg innych ustaleń odnośnie do obejmowanych przez Siegfrieda Degenberga godności kościelnych i w tym przypadku można się pokusić o kilka drobnych uzupełnień. Otóż źródła datowane na 31 III i 15 V 1423 r. podają, że Siegfried Degenberg toczył spór o kanonię wrocławską ${ }^{103}$. Dnia 8 XII 1423 r. otrzymał prowizję na wspomnianą kanonię ${ }^{104}$, która była ponawiana rok później, a następnie w $1425 \mathrm{r}^{105}$ W dniu 4 III 1426 r. złożył obligację annatową ${ }^{106}$. O kanonię i prebendę we Wrocławiu procesował się jednak nadal $27 \mathrm{~V} 1426$ r., a 16 czerwca tego roku otrzymał nawet kolejną prowizję ${ }^{107}$, choć - jak zakłada K. Dola - najpewniej 24 I 1424 r. brał udział w kapitule generalnej ${ }^{108}$. Jako kanonik wrocławski, choć przebywał wówczas

\footnotetext{
${ }^{99}$ Hans Schмаuch, Der Altar des Nicolaus Coppernicus in der Frauenburger Domkirche, ZGAE, Bd. 27: 1942, s. 427.

${ }^{100}$ SBKW, s. 21.

${ }^{101}$ Cäcilie Kuchendorf, Das Breslauer Kreuzstift in seiner persönlichen Zusammensetzung von der Gründung (1288) bis 1456, Breslau 1937, s. 79.

${ }^{102}$ Kazimierz Dola, Wrocławska kapituła katedralna w XV wieku. Ustrój-skład osobowy - działalność, Lublin 1983, s. 344; Stanisław JUJECZKa, Duchowni średniowiecznej Legnicy. Studium prozopograficzne, Legnica 2006, s. 411. Wyklucza jego bawarskie pochodzenie również W. Długokęcki, który ustala dodatkowo brata Siegfrieda, Kristana, który mieszkał w Lasowicach, a najpóźniej od 1447 r. był podobnie jak brat mieszkańcem Wrocławia, zob. W. DŁUGoKęCKI, Elita władzy, s. 67.

${ }^{103}$ RG, Bd. 4, szp. 1569, 3227.

${ }^{104}$ Ibid., szp. 3351. Podana przez T. Borawską data 8 lutego wydaje się pomyłką, por. SBKW, s. 42.

${ }^{105}$ RG, Bd. 4, szp. 3351.

${ }^{106}$ Ibid., szp. 3351-3352.

${ }^{107}$ Ibid., szp. 2091, 3352.

${ }^{108}$ K. Dola, op.cit., s. 344. We Wrocławiu był obecny już 9 I 1424 r., zob. GStA PK, XX. HA, OBA, nr 4231 .
} 
w Budzie, odnotowany został 28 VI 1428 r. ${ }^{109}$ Kolejny raz w gronie kanoników wrocławskich pojawił się 21 II $1430 \mathrm{r}^{110}$, a następnie dopiero 22 IX $1441 \mathrm{r}$. Od tego też roku przybywał na stałe we Wrocławiu ${ }^{111}$, mając do końca życia kanonię przy tamtejszej katedrze ${ }^{112}$. W $1447 \mathrm{r}$. odnotowany został jako jeden $\mathrm{z}$ administratorów diecezji w związku ze śmiercią biskupa Konrada ${ }^{113}$.

Siegfried Degenberg 25 XI 1420 r. otrzymał prowizję na kanonię i prebendę we wrocławskiej kapitule św. Krzyża wakujące po śmierci Konrada Weterheima ${ }^{114}$. O wspomniane beneficjum musiał się jednak procesować. W dniu 8 XII 1423 r. miał jednak altarię we wrocławskim kościele świętokrzyskim ${ }^{115}$. Jako kanonik przy kapitule św. Krzyża odnotowany został pierwszy raz dowodnie 8 XII 1424 r. W tym czasie miał już także kanonię i prebendę w Ołomuńcu, tamtejszą parafię św. Wawrzyńca oraz wikarię przy kolegiacie w Brzegu ${ }^{116}$. Stanisław Jujeczka podawał także, że od $1430 \mathrm{r}$. był prepozytem w Wyszehradzie (prowizję otrzymał w $1427 \mathrm{r} .{ }^{117}$ ). Jako prepozyt wyszehradzki i preszburski jest jednak odnotowywany z całą pewnością już $28 \mathrm{X}$ i 26 XII 1429 r. ${ }^{118}$ Godność prepozyta w Wyszehradzie zachował do końca życia ${ }^{119}$.

Pisząc o Cezarym Watzenrode, autorka nie skorzystała z biogramu, który opracował Robert Ruciński ${ }^{120}$. Jego lektura pozwoliłaby pełniej przedstawić M. Brodzie postać toruńskiego lekarza, $\mathrm{w}$ tym zauważyć, że studiował on w Pradze oraz przez pewien czas związany był z Mazowszem ${ }^{121}$. Johann, znany M. Brodzie lekarz wielkie-

${ }^{109}$ GStA PK, XX. HA, OBA, nr 4954 (28 VI 1428 r.).

${ }^{110}$ RG, Bd. 4, szp. 3352.

${ }^{111}$ K. Dola, op.cit., s. 344 . We Wrocławiu wciąż odnotowywany był m.in. w 1448 r. (zob. GStA PK, XX. HA, OBA, nr 9779) i 1449 r. (?) (zob. GStA PK, XX. HA, OBA, nr 10144).

${ }^{112}$ Jako kanonik wrocławski, a także prepozyt wyszehradzki i były medyk cesarski odnotowany został jeszcze 7 IV, 17 VII, 14 IX i 18-19 IX 1450 r., zob. GStA PK, XX. HA, OBA, nr 10192, 10279, $10365,10370,10372$.

${ }^{113}$ S. JUJECZKA, op.cit., s. 412; K. DoLA, op.cit., s. 182, 344.

${ }^{114}$ RG, Bd. 4, szp. 3351.

${ }^{115}$ Ibid.

${ }^{116}$ Ibid.

${ }^{117}$ Ibid., szp. 3352.

${ }^{118}$ Zob. CDW, Bd. 4: Urkunden der Jahre 1424-35 und Nachträge, hrsg. v. Viktor RöHRICH, Franz LiedtKe, Hans Schmauch, Braunsberg 1935, nr 293; GStA PK, XX. HA, OBA, nr 5239.

${ }^{119}$ Zob. C. KuChENDORF, op.cit., s. 80, przyp. 12.

${ }^{120}$ Zob. Robert Ruciśski, Watzenrode Cezary (przed 1380 - po 1427), mieszczanin tor., dr med., mgr artium, [in:] TSB, t. 3, s. 237.

${ }^{121}$ Być może w latach 1427-1428 przebywał w otoczeniu księcia mazowieckiego Janusza Starszego. Małgorzata Wilska, autorka pracy o środowisku dworskim tego mazowieckiego władcy, uważa, że $\mathrm{w}$ tych latach w jego otoczeniu przebywał pewien doktor medycyny, którego błędnie jednak nazywa Cezarym Krafftem, zob. Małgorzata WiLsKa, Mazowieckie środowisko dworskie Janusza Starszego. Studium społeczne, Warszawa 2012, s. 88. Badaczka błędnie utożsamiła w tym miejscu lekarza, magistra Kraffta, który 26 VI 1428 r. poświadczony został na dworze Janusza (zob. Metryka Księstwa Mazowieckiego z XV-XVI wieku, t. 1: Ksiega oznaczona No 333 z lat 1417-1429, wyd. Aleksander WŁODARSKI, Warszawa 1918, nr 672), z medykiem Cezarym, również w tych latach poświadczonym na dworze władcy. Magister Krafft to znany doskonale badaczom Johann Krafft (zob. Robert RuciŃsKI, Craft Jan (4ćw. XIV w. - 1456), lekarz, mgr, mieszczanin tor., [in:] TSB, t. 3, s. 42-43), a ów Cezary to być może właśnie Cezary Watzenrode. Sprawa wymaga jednak bardziej szczegółowych badań. 
go mistrza, to duchowny tożsamy z Johannem, kanonikiem, a następnie scholastykiem pomezańskim poświadczonym wśród członków tamtejszego kolegium w latach 1340-1345 $5^{122}$. Uzupełniając informacje podane przez autorkę na temat doktora medycyny Petera Landisberga, warto natomiast zauważyć, że był on także odnotowywany na dworze biskupa warmińskiego Franza Kuhschmalza w Lidzbarku ${ }^{123}$.

Na stronie 163, w przypisie 136 M. Broda pisze, że następcą Andreasa Pfaffendorfa na stanowisku plebana gdańskiego był Andreas Kunisch. Warto jednak zaznaczyć w celu uniknięcia ewentualnych niejasności, że nie był on bezpośrednim następcą A. Pfaffendorfa na tym beneficjum. A. Pfaffendorf plebanem w Gdańsku był w 1437 r. ${ }^{124}$, po nim stanowisko to przejął Andreas Ruperti (lata 1438-1447) ${ }^{125}$, a dopiero kolejnym plebanem został A. Kunisch (lata 1447-1455) ${ }^{126}$.

Nie najlepiej wreszcie brzmią używane niekiedy przez M. Brodę wyrażenia typu: „kanonikat w biskupstwie warmińskim” (s. 54), „kanonik diecezji warmińskiej” (s. 60), „kustodia w biskupstwie warmińskim” (s. 116). Należy pisać po prostu o kanonii warmińskiej, kustodii warmińskiej, ewentualnie fromborskiej itd. Taki zapis będzie dużo bardziej zrozumiały i poprawny.

Uwagi i uzupełnienia, jakie niesie ten tekst, nie mogą się stać jednak podstawą do zanegowania pracy M. Brody. Przynoszą one wszak jedynie uzupełnienia do karier osób, które miały medyczne wykształcenie, oraz przedstawiają grono pominiętych medyków, nie wnosząc jednak istotnych danych odnośnie do działalności stricte lekarskiej wspomnianych osób. Autorka książki wykonała wartościową pracę, przybliżając zagadnienia w historiografii podejmowane dotąd marginalnie. Za to należą się jej słowa uznania.

\footnotetext{
${ }^{122}$ M. Glauert, op.cit., s. 461.

${ }^{123}$ Bibliotheca Warmiensis, s. 282.

${ }^{124}$ Zob. jego najnowszy biogram w: M. Sumowski, op.cit., s. 110-113.

${ }^{125}$ Zob. jego najnowszy biogram w: Radosław KrajNiaK, Duchowieństwo kapituly katedralnej w Chetmży do 1466 roku. Studium prozopograficzne, Torun 2013, s. 108-112.

${ }^{126}$ Ibid., s. 106-108.
} 